\title{
Research on the Value Realization of Teachers' Human Capital
}

\author{
Bingfeng Liu and Ningning Yan \\ School of Management and Economics, Jingdezhen Ceramic Institute, Jiangxi Province, China \\ txcf2000@163.com
}

\begin{abstract}
Keywords: Teachers; Human capital; Value realization; Value; Collaborative interaction
\end{abstract}
\begin{abstract}
This paper summarizes the basic characteristics of the human capital; on the basis of the analysis of teachers' human capital value consists of supplementary value, transfer and value creation; finally puts forward the ways to realize the value of human capital of teachers. The research shows that it is necessary to promote the rational flow of teachers' human capital, increase the cultivation of teachers' human capital, realize the value increment of the teachers, and carry out the multi-channel financing to improve the teachers' salary.
\end{abstract}

\section{Introduction}

The characteristics of teachers' human capital has the human capital, but it also has special properties different from the general characteristics, this is because the teachers in the school in this special organization and in the special organization for occupation characteristics of long-term formation of the pursuit of their own development. Therefore, the relationship between teachers' human capital and human capital is the relationship between personality and commonness.

To improve the level of teachers' compensation can improve the enthusiasm of teachers' teaching and research, and ultimately realize the maximization of human capital. In order to set up the financing system of colleges and universities in line with the socialist market economic system, we should set up the financing system of colleges and universities, which is mainly based on the national financial investment, social fund-raising, tuition and miscellaneous fees. Government financial investment is the main way to develop higher education both at home and abroad. Financing social donation is also essential for the development of higher education funds, but in our country, the social donation funds in total in the share is still relatively small, it should strengthen the construction and development of social and political education to encourage more people to participate in higher education. Colleges and universities through the transformation of scientific research achievements, industrial income, social services and other ways to raise funds for education. To raise the efficiency of the use of funds while raising funds for education, so that the limited funds to maximize the effectiveness of. The effective use of existing funds can improve the level of teachers' pay, and then play their enthusiasm.

\section{The Basic Characteristics of Teachers' Human Capital}

Teachers' human capital is formed by the joint investment of universities, teachers and individuals, so teachers' human capital belongs to colleges and universities. The main task of higher education schools is to train senior specialized talents for the society, to promote scientific development, to develop social services. Higher education school teachers' task is around these three aspects, and enhance their own knowledge and enhance the ability of scientific research requires teachers to time, energy, material, money, plus teachers and body of the human capital in physiology are inseparable, teachers can be regarded as the main investors human capital, therefore has the property right of human capital. At the same time, in order to ensure the advanced academic teachers, for the self construction of a high level of education, rational structure of the teaching staff, at present many colleges and universities for teacher education, to participate in academic conferences, academic exchanges, in-service master or $\mathrm{PhD}$ degree to provide material support and work of the party. It can be seen that the human capital of teachers is the result of the joint investment of teachers and universities. Although the investment is different, they all promote the accumulation and increment of human capital. 
According to the principle of "benefit of investment subject", the property rights of teachers' human capital should belong to both. Because of human capital and its carrier in physiology are inseparable, the performance of all the property rights of human capital in the relevant training and education can sign the contract with the teachers, teachers in the event of default, universities can get teachers according to the contract of liquidated damages.

The high input of teachers' human capital is mainly manifested in three aspects: one - time education fee, the following sex education cost, the alternative cost.

First of all, because the high level of education and human capital of teachers in this industry employment requirements, the industry into the threshold is relatively high, and at the entrance to the teacher before the industry needs to be long time and high density in a specialized field, this investment is generally by high levels of education performance, which leads to high input of teachers human capital disposable education.

Secondly, nowadays, with the rapid development of science and technology, the renewal rate of knowledge has been improved, which requires teachers to accept continuing education and to pay for further development in their work. The characteristics of teachers' knowledge around the work determine the high cost of follow-up education. Now the knowledge innovation cycles continue to shorten, students' knowledge and horizons broaden, after entering the university teacher is just started, the need to work with the times, teachers must constantly enrich themselves, improve human capital stock, human capital stock is not only related with the level of education, and teachers also think, in the work of the self self summary, atmosphere is closely related to Teaching benefits teachers as well as students.. In addition, many colleges and universities on the assessment of teachers is very strict. The teachers are facing the dual pressures of teaching and scientific research, scientific research requires a certain quantity and quality, and writing academic papers published, comprehensive assessment of teaching evaluation, including students, all the teachers should constantly update, improve the knowledge structure, education costs a large number of follow-up investment.

In the end, the teachers' working time is relatively high. To give teachers the opportunity cost than the average person, because from the legal age to participate in the work of this period of time by the end of education within the revenue may give up work, is one of the alternative cost expenditure. The alternative cost of teacher spending should also include the income of a teacher who, after taking office, has been able to raise his or her own stock of human capital, continue to pursue a degree or be a visiting scholar. In pursuit of higher education, teachers from undergraduate to master, doctor about ten years to give up a lot of opportunities to make money directly, but also because in a professional in the field of in-depth study, research and development of networking opportunities and lose loss may bring economic benefits. Moreover, teachers in the study period of tuition and so on need to pay, even if there is only a drop in the national subsidy, in summary, the replacement cost of human capital is higher than the general human capital.

The teacher has abundant human capital, is scarce social resources, and thus become universities competing goals, especially since 1999, colleges and universities to expand enrollment, due to economic interests, the academic status of the temptation, driven by teachers with strong liquidity. This is a reasonable under the condition of market economy, with the help of the theory of evolution ", competition can promote the survival of the fittest in natural selection" of human capital accumulation and value, only in the competition to give full play to their subjective initiative, so that the limited material resources to maximize efficiency, make the human capital play a great role.

\section{The Value Composition of Teachers' Human Capital}

The value of teachers' human capital is composed of three parts: value added, value of migration, value creation.

Because teachers need hands-on in daily teaching and scientific research activities, pay their own energy and stamina and sweat, so in this process will reduce the teacher's human capital stock, in order to maintain the productivity of teaching, teachers' Human Capital Normal research then it is necessary 
to reduce production of off teachers in human capital stock. This reduced human capital stock is called the added value.

Because the teacher human capital property common property, society, family, individual, colleges and universities in order to enable teachers to maximize human capital stock will be different degrees of investment for individual teachers, this investment includes both explicit financial and material investment includes recessive spirit, energy investment, these investments will be in different time and different stage of development of irregular migration to the teachers' personal body so as to increase the stock of human capital. This kind of social investment of financial, material, spiritual, spiritual value of the transfer to the individual teachers will become the value of migration, it constitutes a part of the stock of human capital of teachers.

To create value is to create greater value by using its original value. Teachers' teaching, by itself with the human capital research activities, teaching and scientific research achievement is the result of the teachers use their own human capital stock to create new value, that value is created by mental labor, abstract labor of teachers, often greater than the original value. The income multiplier effect, so called 'human capital stock value creation.

\section{The Way to Realize the Value of Teachers' Human Capital}

The characteristics of the high stock of teachers' human capital determine that the competition is so fierce today. For the sake of their own development and promotion, colleges and universities tend to have a strong liquidity. However, the rational flow of teachers is the inevitable requirement of social development, and its practical significance and positive role is beyond doubt. Through the long-term investment of human capital to achieve its value and value, it requires the rational allocation of human capital, and the reasonable flow of teachers is the performance of human resources in the market economy. The rational allocation of resources can reduce the input cost of teachers' human capital, improve the management level of colleges and universities, and increase vitality.

First of all, to establish an interactive mechanism between colleges and universities high-end talent exchange. It is a more flexible mechanism, teachers can not change the original affiliation with the university personnel under the premise of free flow, can be taught in other universities, technology transfer, research. In this way, we can solve the need of the top talents with academic prestige and avoid the loss of teachers' human capital investment. This policy is also beneficial to the universities, the academic exchanges between teachers, different professions, different departments, different opinions between academic exchanges can often arouse thinking sparks, promote innovation. At the same time, in this mechanism, colleges and universities can be configured according to their actual needs of flexible human resources, improve the allocation of resources, so as to achieve the goal of efficient.

Secondly, to promote the exchange of teachers in colleges and universities. Nowadays, it is a common phenomenon that the cross between disciplines, and it is necessary to pursue the depth and breadth of the subject knowledge. It is necessary to organize the academic exchanges of teachers with different professional, different levels and different research directions in a timely manner, so as to create a new academic spark, so that teachers' teaching and scientific research are full of vigor. It is not only helpful for the discovery of major scientific research results, but also for the further development of teachers to form a comprehensive scientific research team. Improve their human capital stock. So as to promote the maximization of the value of human capital.

The innovation of teachers' human capital refers to the accumulation and increment of human capital by the teachers. In order to realize the innovation of human capital, the construction of innovative human capital should do the following:

First, cultivate the innovative consciousness of teachers. From the materialist point of view, the consciousness of the material, only the first with a sense of innovation, in order to promote the creation of the brain consciousness. The innovation consciousness is not only advanced, but also has a huge role 
in promoting social development and progress. Therefore, the innovation consciousness is the forerunner of innovation and the key factor to the success of innovation.

Secondly, it is necessary for teachers to form a good psychological quality. Innovation consciousness from generation to achieve the final success is a long process, during the teaching and research not only to withstand the boring boring, but also by the environment, the influence of the concept, which is bound to cause psychological fluctuation of teachers, affect the academic innovation process. In addition, the innovation of teaching and research is bound to go through many failures in order to achieve success, which challenges the ability of teachers to withstand failure and frustration. Therefore, to train teachers always have a good attitude, can study hard, perseverance, the correct treatment of failure and success, with good psychological quality to have a normal thinking activities.

Third, training teachers' scientific research innovation ability. Scientific research and innovation ability is the core of innovative human capital, the core task of the teacher is the school teaching and scientific research value, so to make the teacher human capital accumulation, innovation, and it must improve the ability of scientific research and innovation. Scientific research innovation refers to the process of understanding, understanding and discovering new knowledge under the premise of understanding and mastering the scientific research achievements, experience and knowledge. We should actively encourage teachers to participate in scientific research activities, independent thinking, independent judgment and independent research tasks, improve their ability of independent innovation.

Fourth, guide teachers to develop innovative learning and work habits. In this fast changing society, every teacher should break the closure, the out of the classroom, to broaden their horizons, make their own exposure to innovative air for the first time, atmosphere and bold to draw their own reality about life, scientific research, the latest insights of academic issues and teach students, the innovative point of view the consciousness of the continuation of life and growth in nature.

Fifth, set up a "fund for the development of teachers' innovative quality will". The foundation of the role and significance of itself, can set up a fund for the development of teachers' innovative quality, the source of fund is the major colleges and universities regularly the cost of delivery as in-service training funds, a stable source of funding can guarantee the stable development of teachers' innovative quality.

\section{Acknowledgement}

This work was supported by the research subject of teaching reform in colleges and universities of Jiangxi province (JXJG-16-11-22/ JXJG-15-11-9).

\section{References}

[1] Wang Libao, Shao Bo. On the particularity of human capital of teachers. Higher education in coal industry, 2008, 26 (6): 65-66.

[2] Li Suxian, Luo Luo. Analysis of the dimensions of human capital value. Journal of Shenyang Normal University, 2008, 32 (6): 126-130.

[3] Wang Zhifeng. Research on the realization of human capital value of teachers in China. Institute of higher education, Xiamen University, 2006. 